\title{
Characterization of Lignin before and after Exposure to the Gastrointestinal Tract of Ruminants
}

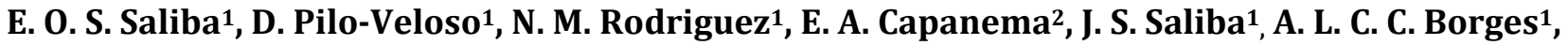 \\ L. C. Gonçalves ${ }^{1}$, I. Borges ${ }^{1}$, D. G. Jayme ${ }^{1}$, R. R. Silva ${ }^{1}$ \\ ${ }^{1}$ Universidade Federal de Minas Gerais, Belo Horizonte, Brazil \\ ${ }^{2}$ Wood and Paper Science Department, North Carolina State University (NCSU), Raleigh, USA \\ Email: saliba@ufmg.br
}

How to cite this paper: Saliba, E.O.S., Pilo-Veloso, D., Rodriguez, N.M., Capanema, E.A., Saliba, J.S., Borges, A.L.C.C., Gonçalves, L.C., Borges, I., Jayme, D.G. and Silva, R.R. (2016) Characterization of Lignin before and after Exposure to the Gastrointestinal Tract of Ruminants. American Journal of Analytical Chemistry, 7, 748-753. http://dx.doi.org/10.4236/ajac.2016.711067

Received: May 6, 2016

Accepted: October 24, 2016

Published: October 27, 2016

Copyright (c) 2016 by authors and Scientific Research Publishing Inc. This work is licensed under the Creative Commons Attribution International License (CC BY 4.0).

http://creativecommons.org/licenses/by/4.0/

(c) (i) Open Access

\begin{abstract}
The aim of this study was to investigate the structural composition of lignin (LIPE ${ }^{\circledast}$ ) extracted from Eucalyptus grandis, before and after exposure to the gastrointestinal tract of ruminants. For this study lignin was isolated, purified and characterized using ${ }^{1} \mathrm{H}$ and ${ }^{13} \mathrm{C}$ Nuclear Magnetic Resonance Spectroscopy, nitrobenzene oxidation, functional groups analysis and gas chromatography with mass spectroscopy. To have a better understanding of lignin morphology and of its ultra structure, electron microscopy in wood cell wall was utilized. The lignin fecal samples showed similar ${ }^{1} \mathrm{H}$ NMR spectrums and nitrobenzene oxidation products compared with LIPE ${ }^{\oplus}$. The result of the microanalysis of LIPE ${ }^{\circledR}$ was similar to data shown in the literature. The ultra structure of lignin was similar to that of Bamboo (hard wood). The lignin isolated from feces of sheep was identical to the original LIPE ${ }^{\oplus}$, which means that this product can be used as an external marker in protein digestibility in sheep.
\end{abstract}

\section{Keywords}

Lignin, Eucalyptus grandis, Ruminant

\section{Introduction}

Use of the term "fiber" was in vogue as early as in the 1800 's, but confirmed largely to refer to forage. The concept of "crude fiber" determined routinely in food and feed as a part of proximate analysis was evolved later to refer to the residue left over after treatment with acid and alkali. The term "dietary fiber" was coined in 1953 to refer to the non-digestible residue in foods [1], but it is mainly applied in human nutrition and it is 
mainly composed of cellulose, hemicelluloses, pectin, lignin, silica and cutin.

Over 500 species of microorganisms are present in the cecum and in the rumen. These fermentors' anaerobic microbes, mainly fiber, produce energy in the form of fatty acids as acetate, propionate and butyrate. However, non-digestible portion of the fiber does not produce energy, and prevents the digestibility of the cell wall by various mechanisms.

Besides the structural polysaccharides, lignin is a main component of cell wall of forages, crop residues and wood and it is indigestible.

The formation of lignin molecule begins with a dimerization of the radical to give dilignols. The dilignols are formed by $\beta-0-4, \beta-5, \beta-\beta$ bonds, and others. These are types of bonds interconnecting aryl propane units in lignins [2]. The continued growth of the molecule takes place primarily by what has been called "end-wise" polymerization [3]. In the lignifying cell there will be a low stationary concentration of the monomer, for instance, coniferyl alcohol. Therefore, dimerization of the monomer radicals will be less favored than their cross coupling with phenotype radicals formed by dehydrogenation of the phenolic end groups of dilignols or larger polymers [2]. The end product is the polymer called lignin.

Studies on the chemical structure of lignin require isolation, characterization by analysis of functional groups; by a series of degradation techniques such as nitrobenzene oxidation, oxidation with permanganate thioacidolysis, GC-MS, and other techniques ${ }^{1} \mathrm{H}$ and ${ }^{13} \mathrm{C}$ NMR spectroscopy.

The nitrobenzene oxidation is a classical method to get an estimate of pattern of the aromatic residues in different lignins, in which p-hydroxyphenyl $(\mathrm{H})$, guaiacyl $(\mathrm{G})$ and syringyl (S) are oxidized to p-hydroxy-benzaldehyde, vanillin and syringaldehyde respectively [3]. The mechanism proceeds through two steps, of which the first is the alkaline hydrolysis of the alkyl aryl ether linkages combined with side chain modification. The second step is the oxidation of the side chain with the generation of aromatic aldehydes of various types which reflect structural features of the parent lignin [4].

In the more recent years Nuclear Magnetic Resonance spectroscopy (NMR) has become a very valuable tool for structural lignin studies and have very interesting results from carbon-13 $\left({ }^{13} \mathrm{C}\right)$ on grass lignin and wood lignin. This study confirms that all three $(\mathrm{H}, \mathrm{G}$, and $\mathrm{S})$ residues are important constituents of these lignins. Their study also reveals that p-coumaric acid and ferulic acid residues also are present. These acids are linked by their phenolic groups via ether bonds to lignin [5].

Advanced ${ }^{1} \mathrm{H}-{ }^{13} \mathrm{C}$ correlation 2D NMR spectroscopic techniques include HMQC (Hetheronuclear Multiple Quantum Coherence) and HMBC.

(Hetheronuclear Multiple Quantum Bond Coherence) sequences provide resolution of overlapping signals with higher probability in correct assignment of the signals, giving a very powerful method to observe qualitative changes in the lignin structure. The HMQC sequence gives information about the correlation between ${ }^{1} \mathrm{H}$ and ${ }^{13} \mathrm{C}$ atoms via one bond coupling $1 \mathrm{~J}(\mathrm{C}, \mathrm{H})$, while the $\mathrm{HMBC}$ sequence provides information about long range correlation between ${ }^{1} \mathrm{H}$ and ${ }^{13} \mathrm{C}$ atoms via two bond coupling, $2 \mathrm{~J}(\mathrm{C}, \mathrm{H})$, and three bond coupling, 3J (C, H). Thus, chemical shifts for carbon and hydrogen in $\mathrm{CH}$, 
$\mathrm{CH}_{2}$, and $\mathrm{CH}_{3}$ groups in a compound can be accurately assigned when the HMQC spectrum of the compound is correlated with the corresponding HMBC spectrum [6].

Many staining techniques have been used in combination with light microscopy to study the distribution of lignin in wood [7]. However, since the advent of electron microscopy, considerable efforts have been made to obtain a better understanding of lignin morphology in wood cell walls. One of the limitations of electron microscopy is that it allows only a visual characterization of the cell structure. Once electron microscopy is combined with energy dispersive X-ray analysis (EDX-A), the system becomes a powerful analytical tool for elucidating the fine details of lignin morphology in wood [8]. In an electron microscope, the incident electron beam impinges upon the specimen and excites the emission of electrons. The emitted electrons are utilized in scanning electron microscopy (SEM) to create a surface image of the specimen on a cathode-ray tube, in contrast to transmission electron microscopy (TEM), which uses transmitted electrons in visualizing the image.

A plant cell consists of core (cell content) and cell wall, which allows the plant to grow thick when age [9]. The supporting tissue has thick walls, lignified or not. The esclerénquima is a lignified tissue, and its function is mechanical [10].

The aim of this study was to characterize the structure of lignin isolated from Eucalyptus grandis before and after exposure to the gastrointestinal tract of sheep to see if it can be used as an external marker in digestibility studies.

\section{Materials and Methods}

1) Wood, isolation, purification of lignin:

The wood utilized was Eucalyptus grandis, six year old. LIPE ${ }^{ø}$ preparation is index patent n PI0304736-9.

2) Feces collection:

Five sheep were distributed in individual metabolic cages, where separate feces and urine, and feces were collected for analysis. The animals were fed $100 \%$ Tifton 85 hay allowing $20 \%$ of remainders and mineral salt ad libtum. The composition of feed is shown in Table 1.

Table 1. Chemical composition the hay.

\begin{tabular}{cc}
\hline & PARAMETERS \% \\
\hline Dry matter (DM) & 89.02 \\
Crude Protein (DP) & 10.38 \\
Ash & 9.19 \\
Neutral detergent fiber (NDF) & 76.88 \\
Acid detergent fiber (ADF) & 55.05 \\
Hemicelluloses & 21.83 \\
Celluloses & 51.32 \\
Ether extract & 2.93 \\
Carbohydrates & 9.80 \\
Crude energy (Kcal/g) & 4.33 \\
\hline
\end{tabular}


The experimental period comprised two days of adaptation with LIPE $^{\circledR}$ and seven days for samples of feces collection. The animals were given $0.1 \mathrm{~g}$ of LIPE ${ }^{\circledR}$ once a day during nine consecutive days.

3) Chemical analyses:

The samples were analyzed by NMR techniques $\left({ }^{1} \mathrm{H}\right.$ and ${ }^{13} \mathrm{C}$ NMR, HMQC) equipment BRUKER AVANCE 500MHZ spectrometer.

Microanalysis was performed at CALI LABORATORIES, North Caroline USA.

Nitrobenzene oxidation products analysis in the GC MS.

4) Electron Microscopy was used for determination of lignin (LIPE ${ }^{\circledast}$ ) ultra structure by a scanning electron microscopy (SEM) using equipment Carl Zeiss MEVDSM 950. The SEM analysis were made after drying $\mathrm{LIPE}^{\circledast}$ in a stove at $39^{\circ} \mathrm{C}$ and made metallic with gold in an equipment CV 052 Balzer.

\section{Results and Discussion}

To check if $\mathrm{LIPE}^{\circledast}$ was altered during the digestive processes, it was analyzed in the original form and isolated from the fecal samples by $\mathrm{NMR}$ techniques $\left({ }^{1} \mathrm{H}\right.$ and ${ }^{13} \mathrm{C}$ NMR, HMQC), nitrobenzene oxidation, microanalysis and electron microscopy.

The fecal samples showed similar ${ }^{1} \mathrm{H}$ NMR spectrums than LIPE ${ }^{\circledR}$, with characteristic signals between: $\delta_{\mathrm{H}} 11.00$ and 9.00 due to formyl hydrogens, $\delta_{\mathrm{H}} 7.00$ to 9.00 due to phenolic and aromatic hydrogens, $\delta_{\mathrm{H}} 6.00$ and 7.00 due to aromatic and $\mathrm{H} \alpha$ in $\beta-O-4$ units hydrogens and $\delta_{\mathrm{H}}$ at 3.77 due to methoxyl hydrogens and also big signals characteristics of carbohydrates between $\delta_{\mathrm{H}} 4.50$ and 5.50 .

The result of the microanalysis was $57.27 \% \mathrm{C}, 4.36 \% \mathrm{H}$ for LIPE $^{\circledast}$ before and after exposure tract digestive. Values for milled wood lignins Eucalyptus grandis are 56.50\% C, $6.40 \% \mathrm{H}$ values are for bamboo $61.66 \%$ C, 5.53\% H [11]. Saliba (1998) studied maize and soybeans lignins found values $\mathrm{C}=61.49 \%$ and $65.49 \%$, respectively. Hydrogen concentration was $6.06 \%$ and $8.44 \%$ for corn and soybeans lignins respectively [12].

The data of nitrobenzene oxidation was vanillin $(\mathrm{V})=49.8 \mathrm{mg} \%$, Syrigaldheide $(\mathrm{S})=$ $50.2 \mathrm{mg} \%$ from $\mathrm{LIPE}^{\otimes}$ and $\mathrm{V}=50.0 \mathrm{mg} \%$ and $\mathrm{S}=49.18 \mathrm{mg} \%$ from feces lignin.

Considering the similar levels of $\mathrm{V}$ and $\mathrm{S}$ in $\mathrm{LIPE}^{\circledast}$ and in the feces of the animals that received $\mathrm{LIPE}^{\otimes}$ it is observed that in the fecal lignin was recovered all the $\mathrm{V}$ and $\mathrm{S}$ given to the animals. Thus, LIPE was totally recovered in the feces, showing that passed through the gastrointestinal tract of sheep without being digested or absorbed which means that it may be used as an effective external marker in digestibility trials with sheep.

The Figure 1 shows the LIPE ${ }^{\circledR}$ SEM. When compared this LIPE ${ }^{\circledast}$ with the corn lignin showed by Saliba [13] and that showed by Fengel \& Wegerner [11], the ultra structure of $\mathrm{LIPE}^{\circledast}$ was similar of the Bamboo (hard wood).

Lignin degradation is an oxidative process and needs the presence of oxygen. In fact, lignin is degraded much faster in the presence of pure oxygen than in the presence of air, and ligninolytic activity is not observed under low oxygen partial pressures (5.07 $\mathrm{Pa}$. Therefore, lignin degradation is affected by oxygen at two stages, firstly stimulating 


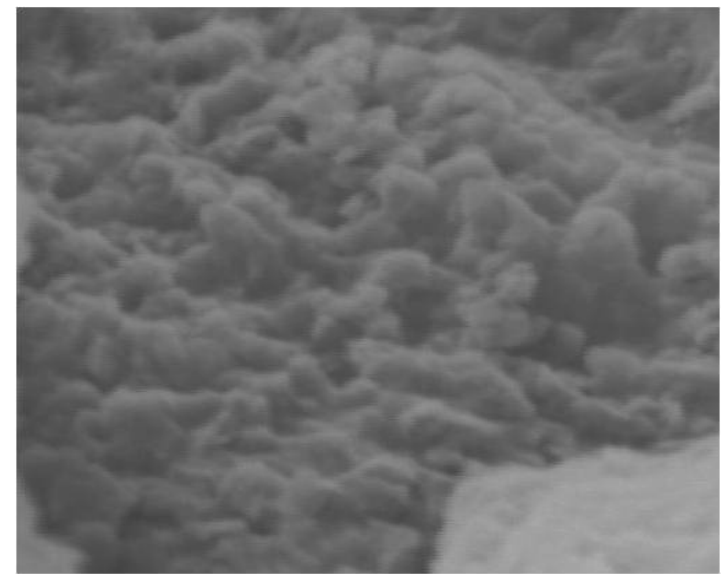

Figure 1. LIPE ${ }^{\circledR}$ SEM (20000 higher).

the transcription of the ligninolytic enzyme system and secondly at the time of oxidation of lignin [14]. Based on these concepts, pure lignin should not be degraded in the rumen of ruminants, and since non-ruminant are not able to metabolize lignin, purified lignin may also be able to be used as an external marker of fecal output in those animals.

\section{Conclusion}

The lignin isolated from feces of sheep was identical to the original LIPE ${ }^{\varpi}$, which means that this product can be used as an external marker in protein digestibility in sheep.

\section{References}

[1] Potty, W.H. (1996) Physio-Chemical Aspects, Physiological Functions, Nutritional Importance and Technological Significance of Dietary Fibers-A Critical Appraisal. Journal of Food Science and Technology, 33, 1-18.

[2] Adler, E. (1977) Lignin Chemistry-Past, Present and Future. Wood Science and Technology, 11, 169-218. http://dx.doi.org/10.1007/BF00365615

[3] Sarkanem, K.V. and Ludwig, C.H. (1971) Definition and Nomenclature. In: Sarkanen, K.V. and Ludwig, C.H., Eds., Lgnins Occurrence, Formation, Structure and Reactions, Wiley Interscience, New York, 43-95.

[4] Chang, H.M. and Allan, G.G. (1971) Oxidation. In: Sarkanen, K.V. and Ludwig, C.H., Eds., Lignins: Occurrence, Formation, Structure, and Reactions, Wiley Interscience, New York, 433.

[5] Nimz, H.H., Robert, D., Faix, O. and Nemi, M. (1981) Carbon-13 NMR Spectra of Lignins, 8. Structural Differences between Lignins of Hardwoods, Grasses and Compression Wood. Holzforschung, 35, 16-26. http://dx.doi.org/10.1515/hfsg.1981.35.1.16

[6] Capanema, E.A., Balakshin, M.Y., Chen, C.L., Gratzl, J.S. and Gracz, H. (2001) Structural Analysis of Residual and Technical Lignins by ${ }^{1} \mathrm{H}-{ }^{13} \mathrm{C}$ Correlation 2D NMR-Spectroscopy. Holforschung, 55, 302-308. http://dx.doi.org/10.1515/hf.2001.050

[7] Brauns, F.E. (1952) The Chemistry of Lignin. Academic Press, New York, 24-48.

[8] Saka, S. (1992) Electron Microscopy. In: Lin, S.Y. and Dence, C.W., Eds., Methods in Lignins Chemistry, Springer Series in Wood Science, Ed. T.E. Timell, New York, 133-145. 
http://dx.doi.org/10.1007/978-3-642-74065-7_10

[9] Jarrige, R., Demarquilly, C., et al. (1995) Les constituants de l'appareid vegetatif des plantes fourrageres. In: Jarrige, R., Ruckebusch, Y. and Dermarquilly, C., Eds., Nutrition des ruminants domestiques, ingestion et digestion, INRA, Paris, 25-82.

[10] Saliba, E.O.S., Rodriguez, N.M., Goncalves, L.C., Faria, E.P. and Pilo-Veloso, D. (1999) Caracterizacao microscopica da lignina dos residuos agricolas de milho e soja submetidos a fermentacao ruminal e seus efeitos sobre a digestibilidade da fibra. Arquivo Brasileiro de Medicina Veterinária e Zootecnia, Belo Horizonte, 51, 89-96.

[11] Fengel, D. and Wegener, G. (1984) Wood, Chemistry, Ultrastructure, Reactions. Waster \& Grugter, New York, 613 p.

[12] Saliba, E.O.S., Rodriguez, N.M., Barreto, S.L.T. and Pilo-Veloso, D. (1998) Isolation and Infrared Spectroscopic Characterization of Lignin from Both Corn and Soybean Agricultural Residues. Arquivo Brasileiro de Medicina Veterinária e Zootecnia, 50, 727-730.

[13] Saliba, E.O.S. (1998) Caracterizacao quimica e microscopica das ligninas do residuo agricola de milho e de soja submetidos a fermentacao ruminal e seus efeitos sobre a digestibilidade da fibra. Tese de Doutorado, Escola de Veterinaria UFMG, Belo Horizonte, 251 p.

[14] Villas-Boas, S.G., Eposito, E. and Mitchell, D.A. (2002) Microbial Conversion of Lignicellulosic 1 Production of Animal Feeds. Animal Feed Science and Technology, 98, 1-12. http://dx.doi.org/10.1016/S0377-8401(02)00017-2

\section{Submit or recommend next manuscript to SCIRP and we will provide best service for you:}

Accepting pre-submission inquiries through Email, Facebook, LinkedIn, Twitter, etc. A wide selection of journals (inclusive of 9 subjects, more than 200 journals)

Providing 24-hour high-quality service

User-friendly online submission system

Fair and swift peer-review system

Efficient typesetting and proofreading procedure

Display of the result of downloads and visits, as well as the number of cited articles

Maximum dissemination of your research work

Submit your manuscript at: http://papersubmission.scirp.org/

Or contact ajac@scirp.org 